\title{
KEMANDIRIAN BELAJAR MAHASISWA PENDIDIDIKAN MATEMATIKA UNIVERSITAS PASIR PENGARAIAN
}

\author{
Annajmi \\ Program Studi Pendidikan Matematika Universitas Pasir Pengaraian \\ email: annajminajmi86@gmail.com
}

\begin{abstract}
ABSTRAK. Penelitian ini mengkaji kemandirian belajar mahasiswa pendidikan matematika Universitas Pasir Pengaraian. Tujuan penelitian ini adalah mendeskripsikan kemandirian belajar mahasiswa pendidikan matematika Universitas Pasir Pengaraian. Metode penelitian ini adalah penelitian deksriptif dengan sampel mahasiswa yang mengambil matakuliah matematika diskrit tahun akademik 2018/2019. Instrumen yang digunakan adalah angket kemandirian belajar. Hasil angket mendeskripsikan kemandirian belajar mahasiswa secara keseluruhan yaitu $57,58 \%$ dengan kategori sedang dan sisanya pada kategori tinggi yaitu $42,42 \%$. Apabila dilihat dari 4 (empat) aspek kemandirian belajar yang diukur yaitu kesadaran berpikir dalam belajar matematika sebesar $45,45 \%$ pada kategori tinggi dan 54,55\% pada kategori sedang, sementara itu pada aspek pendekatan pembelajaran berbasis masalah dalam diskusi kelompok $42,42 \%$ pada kategori tinggi dan $57,58 \%$ pada kategori sedang, sedangkan aspek motivasi dalam belajar matematika terdapat $45,45 \%$ pada kategori tinggi dan $51,52 \%$ pada kategori sedang, aspek keyakinan dalam belajar matematika terdapat $2 \%$ pada kategori sangat tinggi dan 12,12\% pada kategori tinggi, 57,58\% pada kategori sedang, terdapat 24,24\% pada kategori rendah. Hasil ini menunjukkan secara keseluruhan ataupun masingmasing aspek kemandirian belajar lebih dari 50\% berada pada kategori sedang, artinya kemandirian belajar mahasiswa dalam belajar matematika diskrit masih belum cukup baik. Hal ini menunjukkan mahasiswa masih harus diberikan tanggung jawab dalam melaksanakan tugas atau untuk belajar secara mandiri.
\end{abstract}

Kata-kata Kunci : kemandirian belajar, matematika diskrit, pendidikan matematika.

\section{PENDAHULUAN}

Keberhasilan dalam suatu pembelajaran, tentunya ditentukan oleh usaha dan kerja keras dari seorang mahasiswa yang dilakukan secara maksimal dengan kesadarannya sendiri. Hal ini ditandai dengan kesiapan seoarang mahasiswa untuk mengikuti suatu perkuliahan maupun dalam menyelesaikan suatu tugas yang diberikan dengan tepat waktu. Kemandirian belajar (self regulated learning), berkaitan erat dengan pengaturan diri dalam belajar, yang juga merupakan salah satu ciri dari pengaturan diri yang baik, yaitu menyelesaikan tugas tepat waktunya (Dina \& Nugraheni, 2017). Kemandirian dalam hal ini berkaitan dengan pengaturan diri seorang mahasiswa dalam menyelesaikan suatu tugasnya. Self-regulated learning ditandai dengan kemampuan seseorang untuk memahami dan mengontrol dirinya dalam suatu lingkungan belajar (Haris \& Graham, 1999). Mengontrol diri berarti, berkaitan dengan kemampuan seseorang yang meliputi penetapan tujuan, pemantauan diri, pengajaran sendiri, dan penguatan diri. Sebagaimana yang dinyatakan oleh Zimmerman, Bonner, \& Kovach, (2002) yaitu self-regulation should 
not be confused with a mental ability or an academic performance skill. Hal ini berarti bahwa pengaturan diri tidak boleh dikacaukan dengan kemampuan mental atau keterampilan kinerja akademik. Sebaliknya, pengaturan diri adalah proses pengarahan diri sendiri dan serangkaian perilaku di mana peserta didik mengubah kemampuan mental mereka menjadi keterampilan.

Zumbrunn, (2011) menyatakan bahwa self regulated learning adalah sebuah proses yang membantu siswa dalam mengelola pikiran, perilaku, dan emosi mereka agar dapat dengan sukses menentukan pengalaman belajar mereka. Hal ini berarti kemandirian juga berkaitan dengan proses yang dilakukan oleh seorang mahasiswa yang membantu dalam mengatur tingkah laku dan emosinya untuk mampu mengarahkan pengalaman belajarnya. Berkaitan dengan itu sikap mandiri bagi seorang mahasiswa merupakan salah satu faktor penentu keberhasilan hasil belajar mahasiswa dalam suatu pembelajaran. Permendikbud Nomor 20 Tahun 2003 telah menjelaskan bahwa siswa (mahasiswa) diharapkan menjadi manusia yang beriman, bertakwa kepada Tuhan Yang Maha Esa, berakhlak mulia, sehat, berilmu, cakap, kreatif, mandiri dan menjadi warga negara yang demokratis dan bertanggung jawab. Selain itu Shifatun (Syibli, 2018) juga mengatakan bahwa bonus demografi yang akan diperoleh Indonesia pada tahun 2045 adalah menghasilkan sumber daya manusia (SDM) yang memiliki sikap inisiatif dan mandiri guna bersaing dengan SDM negara lain. Mahasiswa yang merupakan bagian dari sumber daya manusia Indonesia memiliki peranan yang tinggi tinggi untuk kemajuan Indonesia. Hal ini tentunya mahasiswa perlu memiliki sikap mandiri tersebut. Sebagaimana yang dikatakan oleh Yuningrih (Syibli, 2018) bahwa mandiri sebagai salah satu sikap yang harus dimiliki oleh setiap siswa. Sikap mandiri ini penting dimiliki mahasiswa khususnya dalam mengikuti pembelajaran yang diharapkan dapat diterapkan dalam kehidupan bermasyarakat. Sikap mandiri merupakan suatu sikap dan perilaku yang tidak mudah tergantung pada orang lain dalam menyelesaikan tugas-tugas (Kemendiknas, 2010). Sikap mandiri penting dimiliki oleh setiap mahasiswa guna menghasilkan Sumber Daya Manusia (SDM) yang kuat dan berkualiyas yang berdaya saing sehingga mampu bersaing dengan kemajuan zaman yang cepat berubah. Hal ini dikarenakan, bahwa seseorang yang mandiri memiliki prilaku yang eksploratif, dapat mengambil keputusan percaya diri dan kreatif, selain itu juga mampu bertindak kritis tidak takut berbuat sesuatu, mempunyai kepuasan dalam melakukan aktivitasnya dan mampu menerima realitas (Monk, Knoers, \& Haditono, 2004).

Sikap mandiri dalam belajar atau kemandirian belajar (Self regulated learning) dapat dikatakan sebagai suatu kesadaran mahasiswa dalam mempelajari suatu topik pembelajaran dan menyelesaikan tugas tugas yang diberikan serta memanfaatkan sumber belajar termasuk kemajuan teknologi dalam belajar. Menurut Trisianawati \& Anita, (2016) kemandirian dalam belajar merupakan sebuah usaha yang timbul dari dalam diri seseorang yang didasari oleh motivasinya sendiri untuk menguasai suatu materi tertentu sehingga dapat digunakan dalam menyelesaikan suatu permasalahan. Sikap mandiri dapat dilihat dari bagaimana cara mahasiswa belajar dalam mengikuti pembelajaran yang diberikan di kampus. Kemandirian belajar 
merupakan proses belajar yang didorong atas kemauan sendiri, pilihan sendiri serta mampu mempertanggungjawabkan tindakannya (Dina \& Nugraheni, 2017). Apabila mahasiswa dalam belajar belum memiliki sikap mandiri yang baik, dikhawatirkan dalam melaksanakan tugas-tugas dan hal lainnya yang ada dalam kehidupan bermasyarakat, dimana memerlukan lebih banyak kemandirian dalam melaksanakannya tidak mampu dilaksanakan secara mandiri pula. Seorang yang memiliki sikap mandiri akan terlihat dari tanggungjawabnya dalam melaksanakan suatu tugas yang diberikan, dalam mencapai keberhasilan yang diharapkannya. Sikap mandiri penting dimiliki, juga disampaikan oleh Bramucci, (2013) beberapa alasan yaitu self regulated learning changes occur on the basis of growth and development on: an understanding of the role one's own skills and effort play in performance; expectations of the control trheshold that they can exercises; an understanding of the nature of the task; the quality of the strategies that they construct and adopt. Pernyataan tersebut menjelaskan bahwa kemandirian belajar memberikan perubahan berdasarkan pada pertumbuhan dan perkembangan, sehingga keterampilan dalam memahami dan sebagai aturan dalam keterampilan dan upaya seseorang untuk memperoleh pengalamannya yang berkualitas.

Mahasiswa pendidikan matematika sebagai calon pendidik dan pemimpin masa depan bangsa, perlu mempersiapkan diri menjadi mahasiswa yang berkualitas dan berdaya saing sehingga mampu menghadapi perubahan zaman yang sangat cepat berubah secara mandiri. BsY, (2010) menyatakan bahwa karakteristik kemandirian belajar siswa maupun mahasiswa yang dikembangkan dalam pembelajaran kognitif diantaranya yaitu: (1) memilih tujuan benar; (2) menyelesaikan kesulitan; (3) pemanfaatan fasilitas; (4) sikap kooperatif: (5) membangun makna; (6) kontrol diri (Akhdiyat \& Hidayat, 2018). Hal ini berarti mahasiswa yang mandiri akan memiliki kepercayaan diri atas kemampuan yang dimilikinya tanpa harus berpedoman pada pekerjaan teman, selain itu mahasiswa akan berani mengungkapkan gagasannya atas apa yang dipikirkannya. Goodman dan Smart (1992:42) mengungkapkan bahwa dalam kemandirian terdapat tiga aspek yaitu 1) independent yaitu perilaku yang aktifitasnya diarahkan pada diri sendiri, tidak mengharapkan arahan dari orang lain, melainkan mencoba sendiri dalam menyelesaikan permasalahan yang dihadapi tanpa meminta pertolongan orang lain, 2) autonomi yaitu kecenderungan dalam berperilaku dengan bebas dan original dan 3) self reliance yaitu perilaku yang didasarkan atas kepercayaan diri sendiri. Aspek aspek dari kemandirian belajar juga dapat dilihat dari kesadaran berpikir dalam belajar matematika, pendekatan pembelajaran berbasis masalah dalam diskusi kelompok, dan motivasi dalam belaajr matematika, dan keyakinan dalam belajar matematika (Minarmi, Lubis dan Annajmi, 2018).

Beberapa karakteristik dari kemandirian belajar ini, tidak begitu terlihat dalam perkuliahan matematika diskrit yang dilaksanakan. Berdasarkan hasil pengamatan terhadap perkuliahan matematika diskrit terdapat beberapa temuan yang berkaitan dengan kemandirian belajar, diantaranya adanya mahasiswa yang tidak percaya diri atas kemampuannya sehingga sering kali melihat ataupun berpedoman pada 
jawaban temannya dalam mengerjakan tugas. Mahasiswa juga tidak berani mengemukakan pendapatnya dan lebih banyak diam termasuk dalam hal bertanya. Ketika dosen memberikan penugasan, mahasiswa tampak sekali tidak mempelajari materi yang ditugaskan. Ini menunjukkan mahasiswa belum dapat merancang belajar mereka sendiri. Hasilnya mahasiswa kurang berkonsentrasi dan kurang aktif dalam perkuliahan. Kondisi tersebut tentunya juga akan memberikan dampak secara tidak langsung pada hasil belajar mahasiswa dalam perkuliahan. Mahasiswa lebih banyak belajar ketika akan mengikuti ujian dan ketika ada tugas yang diberikan.

Berkaitan dengan berbagai penjelasan mengenai kemandirian belajar (self regulate learning), dalam hal ini diperlukan suatu kajian untuk mendeskripsikan kemandirian belajar mahasiswa dalam belajar. Oleh karena itu, diperlukan suatu penelitian yang bertujuan untuk mendeskripsikan kemandirian belajar mahasiswa dalam perkuliahan matematika diskrit.

\section{METODE PENELITIAN}

Penelitian ini menggunakan metode deskriptif, yang bertujuan untuk mengetahui dan menganalisis kemandirian belajar matematis mahasiswa pada perkuliahan mata kuliah matematika diskrit. Penelitian ini dilaksanakan dengan memberikan angket kemandirian belajar diakhir semester pada perkuliahan matematika diskrit. Populasi yang digunakan adalah mahasiswa program studi pendidikan matematika FKIP Universitas Pasir Pengaraian. Pemilihan sampel menggunakan purposive sampling yaitu mahasiswa yang mengambil mata kuliah matematika diskrit yang berjumlah 33 orang mahasiswa.

Instrumen dalam penelitian ini menggunakan instrumen non tes. Instrumen non tes digunakan untuk mengetahui kemandirian belajar mahasiswa dalam perkuliahan matematika diskrit. Angket kemandirian belajar matematis mahasiswa sebanyak 50 pernyataan dengan 4 pilihan jawaban, yaitu SS (Sangat Setuju), S (Setuju), TS (Tidak Setuju), dan STS (Sangat Tidak Setuju). Adapun angket kemandirian belajar siswa disusun sesuai aspek-aspek, yaitu

Tabel 1. Aspek dan Indikator Kemandirian Belajar

\begin{tabular}{|c|c|}
\hline Aspek yang Diukur & Indikator \\
\hline \multirow[t]{2}{*}{$\begin{array}{l}\text { Kesadaran berpikir dalam } \\
\text { belajar matematika }\end{array}$} & $\begin{array}{l}\text { Siswa menunjukkan inisiatif dalam belajar } \\
\text { matematika }\end{array}$ \\
\hline & $\begin{array}{l}\text { Siswa mendiagnosis kebutuhan dalam belajar } \\
\text { matematika }\end{array}$ \\
\hline \multirow{4}{*}{$\begin{array}{l}\text { Pendekatan pembelajaran } \\
\text { berbasis masalah dalam } \\
\text { diskusi kelompok }\end{array}$} & Siswa mengatur dan mengontrol belajar \\
\hline & $\begin{array}{l}\text { Siswa mengatur dan mengontrol kognisi, motivasi } \\
\text { dan perilaku dalam belajar matematika }\end{array}$ \\
\hline & Siswa memilih dan menerapkan strategi belajar \\
\hline & mengevaluasi proses dan hasil belajar \\
\hline $\begin{array}{l}\text { Motivasi dalam } \\
\text { matematika }\end{array}$ & $\begin{array}{l}\text { Siswa dapat memandang kesulitan sebagai } \\
\text { tantangan }\end{array}$ \\
\hline
\end{tabular}


Indikator

Siswa mencari dan memanfaatkan sumber belajar yang relevan

Keyakinan dalam belajar Siswa yakin tentang dirinya sendiri matematika

(Minarni, Lubis, \& Annajmi, 2018)

Data hasil penelitian diolah dan dianalisis menggunakan statistik deskriptif. Data hasil angket kemandirian belajar, diklasifikasikan sesuai dengan persentase perolehan mahasiswa yang disajikan pada Tabel 2.

Tabel 2. Penilaiaan Tingkat Kemandirian Belajar Mahasiswa

\begin{tabular}{cc}
\hline Interval & Kriteria \\
\hline $85 \% \leq \mathrm{KB} \leq 100 \%$ & Sangat Tinggi \\
\hline $69 \% \leq \mathrm{KB}<86 \%$ & Tinggi \\
\hline $53 \% \leq \mathrm{KB}<69 \%$ & Sedang \\
\hline $37 \% \leq \mathrm{KB}<52 \%$ & Rendah \\
\hline $20 \% \leq \mathrm{KB}<36 \%$ & Sangat Rendah \\
\hline
\end{tabular}

(Hendrayana, Thaib, \& Rosnenty, 2014)

\section{HASIL DAN PEMBAHASAN}

Data hasil kemandirian belajar mahasiswa yang diperoleh dari angket yang diberikan kepada mahasiswa diakhir semester, selanjutnya dianalisis dengan mengkonversi skor peroleh masing-masing mahasiswa menjadi data persentase. Adapun hasil angket kemandirian belajar mahasiswa dalam perkuliahan matematika diskrit disajikan pada Tabel 3.

Tabel 3. Penilaiaan Tingkat Kemandirian Belajar Mahasiswa

\begin{tabular}{cccc}
\hline \multicolumn{1}{c}{ Interval } & Frekuensi & Persentase & Kriteria \\
\hline $85 \% \leq \mathrm{KB} \leq 100 \%$ & 0 & 0 & Sangat Tinggi \\
\hline $69 \% \leq \mathrm{KB}<86 \%$ & 14 & 42,42 & Tinggi \\
\hline $53 \% \leq \mathrm{KB}<69 \%$ & 19 & 57,58 & Sedang \\
\hline $37 \% \leq \mathrm{KB}<52 \%$ & 0 & 0 & Rendah \\
\hline $20 \% \leq \mathrm{KB}<36 \%$ & 0 & 0 & Sangat Rendah \\
\hline Jumlah & $\mathbf{3 3}$ & $\mathbf{1 0 0 \%}$ & \\
\hline
\end{tabular}

Tabel 3 memperlihatkan gambaran tingkat kemandirian belajar mahasiswa dalam mengikuti perkuliahan matematika diskrit. Mahasiswa memiliki sikap mandiri yang hanya $42,42 \%$ pada kategori tinggi dan lebih dari 50\% berada pada kategori sedang yaitu 57,58\%. Hal ini menunjukkan bahwa kemandirain belajar mahasiswa masih dibawah 50\%, dan lebih besar pada kategori sedang, dengan demikian mahasiswa masih belum memiliki sikap mandiri yang cukup baik dalam belajar, baik dalam menyelesaikan tugas-tugas yang diberikan maupun mengulang kembali materi perkuliahan yang dilakukan di rumah maupun di kampus. 
Berdasarkan hasil angket kemandirian belajar yang diperoleh, juga dapat dilihat kemandirian belajar mahasiswa pada masing-masing aspek dari angket kemandirian yang diberikan. Adapun hasil kemandirian belajar mahasiswa dilihat berdasarkan aspek kemandirian yang diukur disajikan pada Tabel 4.

Tabel 4. Kesadaran berpikir dalam belajar matematika

\begin{tabular}{cccc}
\hline Interval & Frekuensi & Persentase & Kriteria \\
\hline $85 \% \leq \mathrm{KB} \leq 100 \%$ & 0 & 0 & Sangat Tinggi \\
\hline $69 \% \leq \mathrm{KB}<86 \%$ & 15 & 45,45 & Tinggi \\
$53 \% \leq \mathrm{KB}<69 \%$ & 18 & 54,55 & Sedang \\
$37 \% \leq \mathrm{KB}<52 \%$ & 0 & 0 & Rendah \\
\hline $20 \% \leq \mathrm{KB}<36 \%$ & 0 & 0 & Sangat Rendah \\
\hline Jumlah & $\mathbf{3 3}$ & $\mathbf{1 0 0 \%}$ & \\
\hline
\end{tabular}

Tabel 4. Memperlihatkan gambaran tingkat kesadaran mahasiswa dalam berpikir untuk belajar matematika, dapat dilihat bahwa mahasiswa yang memiliki kesadaran berpikir dalam belajar matematika yaitu terdapat $45,45 \%$ pada kategori tinggi, hal ini masih dibawah $50 \%$ dari jumlah siswa. Sementara itu terdapat 54,55\% pada kategori sedang mahasiswa yang memiliki kesadaran berpikir dalam belajar matematika. Hal ini menunjukkan mahasiswa masih belum cukup baik memiliki kesadaran untuk bisa belajar secara mandiri, baik menyelesaikan tugas-tugas yang diberikan ataupun mengulang kembali materi yang dipelajari sebelumnya. Apabila diperhatikan dari jawaban mahasiswa dalam pengisian angket, mahasiswa baru belajar ketika ada tugas yang diberikan dan ketika ujian akan dilaksanakan. Tugas-tugas tersebut pun dikerjakan atau diselesaikan di kampus sebelum perkuliahan dimulai.

Gambaran lain dari aspek yang diukur untuk kemandirian belajar selanjutnya, dapat dilihat pada Tabel 5.

Tabel 5. Pendekatan pembelajaran berbasis masalah dalam diskusi kelompok

\begin{tabular}{cccc}
\hline Interval & Frekuensi & Persentase & Kriteria \\
\hline $85 \% \leq \mathrm{KB} \leq 100 \%$ & 0 & 0 & Sangat Tinggi \\
$69 \% \leq \mathrm{KB}<86 \%$ & 14 & 42,42 & Tinggi \\
\hline $53 \% \leq \mathrm{KB}<69 \%$ & 19 & 57,58 & Sedang \\
\hline $37 \% \leq \mathrm{KB}<52 \%$ & 0 & 0 & Rendah \\
\hline $20 \% \leq \mathrm{KB}<36 \%$ & 0 & 0 & Sangat Rendah \\
\hline Jumlah & 33 & $100 \%$ & \\
\hline
\end{tabular}

Tabel 5 memberikan gambaran terhadap kemandirian belajar mahasiswa, apabila dilihat dari aspek pendekatan pembelajaran berbasis masalah dalam diskusi kelompok, dimana mahasiswa memiliki kriteria tinggi sebesar $42,42 \%$, namun hal ini 
masih dibawah $50 \%$ dari jumlah siswa, sementara pada kriteria sedang terdapat $57,58 \%$ mahasiswa yang bisa belajar melalui pendekatan pembelajaran berbasis masalah dalam diskusi kelompok. Hal ini berarti mahasiswa masih belum cukup baik untuk bisa belajar secara mandiri dengan berdiskusi kelompok, mereka masih menyukai belajar atau mengerjakan tugas secara individu dari pada berdiskusi kelompok.

Gambaran lain dari aspek yang diukur untuk kemandirian belajar selanjutnya, dapat dilihat pada Tabel 6.

Tabel 6. Motivasi dalam belajar matematika

\begin{tabular}{cccc}
\hline Interval & Frekuensi & Persentase & Kriteria \\
\hline $85 \% \leq \mathrm{KB} \leq 100 \%$ & 0 & 0 & Sangat Tinggi \\
$69 \% \leq \mathrm{KB}<86 \%$ & 15 & 45,45 & Tinggi \\
$53 \% \leq \mathrm{KB}<69 \%$ & 17 & 51,52 & Sedang \\
\hline $37 \% \leq \mathrm{KB}<52 \%$ & 1 & 3,03 & Rendah \\
\hline $20 \% \leq \mathrm{KB}<36 \%$ & 0 & 0 & Sangat Rendah \\
\hline Jumlah & $\mathbf{3 3}$ & $\mathbf{1 0 0 \%}$ & \\
\hline
\end{tabular}

Tabel 6 menggambarkan motivasi mahasiswa dalam belajar matematika, dimana terdapat 45,45\% mahasiswa berada pada kategori tinggi, dan terdapat 51,52\% berada pada ketogiri sedang, sementara itu terdapat 3,03\% yang berada pada kategori rendah. Hal ini berarti bahwa mahasiswa masih belum memiliki motivasi yang cukup baik untuk bisa belajar secara mandiri baik dalam menyelesaikan tugas yang diberikan ataupun mengulang kembali materi yang telah dipelajari sebelumnya.

Gambaran lain dari aspek yang diukur untuk kemandirian belajar selanjutnya, dapat dilihat pada Tabel 7.

Tabel 7. Keyakinan dalam belajar matematika

\begin{tabular}{cccc}
\hline Interval & Frekuensi & Persentase & Kriteria \\
\hline $85 \% \leq \mathrm{KB} \leq 100 \%$ & 2 & 6,06 & Sangat Tinggi \\
\hline $69 \% \leq \mathrm{KB}<86 \%$ & 4 & 12,12 & Tinggi \\
$53 \% \leq \mathrm{KB}<69 \%$ & 19 & 57,58 & Sedang \\
$37 \% \leq \mathrm{KB}<52 \%$ & 8 & 24,24 & Rendah \\
\hline $20 \% \leq \mathrm{KB}<36 \%$ & 0 & 0 & Sangat Rendah \\
\hline Jumlah & $\mathbf{3 3}$ & $\mathbf{1 0 0 \%}$ & \\
\hline
\end{tabular}

Berdasarkan Tabel 7 memperlihatkan bahwa mahasiswa, sesungguhnya memiliki keyakinan dalam belajar matematika, dimana terdapat $6,06 \%$ yang berada pada kategori sangat tinggi dan 12,12\% pada kategori tinggi. Namun demikian terdapat 24,24\% berada pada kategori rendah untuk keyakinan mahasiswa dalam belajar matematika. Sementara itu lebih dari $50 \%$ mahasiswa berada pada kategori sedang 
untuk keyakinan dalam belajar, yaitu 57,58\% dari jumlah seluruh mahasiswa. Hal ini berarti secara keseluruhan masih belum memiliki kepercayaan diri terhadap kemampuannya dalam belajar matematika. Apabila dilihat dari beberapa jawaban yang diberikan terdapat mahasiswa yang menjawab angket kemandirian untuk aspek keyakinan dalam belajar ini, mereka bisa menyelesaikan tugas yang diberikan namun tidak percaya diri dalam mengungkapkannya.

Persentase mengenai kemandirian belajar mahasiswa yang ditampilkan berdasarkan hasil analisis data memberikan gambaran bahwa secara keseluruhan kemandirian belajar mahasiswa lebih dari 50\% berada pada kategori sedang. Hal ini menunjukkan bahwa mahasiswa masih harus diberikan tanggung jawab dalam melaksanakan tugas atau untuk belajar secara mandiri, karena sikap mandiri sangat diperlukan, agar mampu bersaing menghadapi perubahan zaman yang begitu cepat. Haryono (2001) menjelaskan bahwa kemandirian belajar perlu diberikan kepada peserta didik supaya mereka mempunyai tanggungjawab dalam mengatur dan mendisiplinkan dirinya dalam mengembangkan kemampuan belajar atas kemavan sendiri. Selain itu Mujiman, (2007) juga menyatakan bahwa belajar mandiri merupakan kegiatan belajar aktif, yang didorong oleh motivasi mengenai suatu kompetensi yang dimiliki. Selain itu kemandirian belajar juga merupakan kombinasi antara keterampilan belajar akademik dan pengendalian diri yang membuat pembelajaran menjadi lebih mudah, sehingga peserta didik (mahasiswa) lebih termotivasi (Glynn, Aultman, \& Owens, 2005). Hal ini berarti apabila mahasiswa memiliki kemandirian dalam belajar secara tidak langsung juga akan memberikan pengaruh terhadap prestasi belajar matematika mahasiswa tersebut. Kemandirian belajar yang dimiliki siswa akan menjadikan mahasiswa untuk lebih mampu dalam mengatur belajarnya sendiri dan dapat meningkatkan hasil belajar mereka (Steffens, 2006).

Berkaitan dengan itu perlu diciptakan suasana akademik untuk menghasilkan mahasiswa sebagai sumber daya manusia yang ideal dan mempunyai kemampuan yang berimbang antara hard skill dan soft skill. Suatu kebiasaaan yang terjadi dimasyarakat bahwa mahasiswa dianggap berkualitas apabila mempunyai IPK tinggi. Kondisi di lapangan, dapat dikatakan bahwa dunia pendidikan selama ini hanya terfokus pada bagaimana mengejar prestasi akademik mahasiswa yang ditandai dengan tingginya Indeks Prestasi Komulatif (IPK) pada setiap akhir semester. Hal ini sesungguhnya bukan sesuatu yang salah, melainkan apabila kemampuan akademis dijadikan satu-satunya indikator keberhasilan pembelajaran, tentunya belum memadai. Berdasarkan data hasil penelitian ini, masih belum maksimalnya sikap mandiri mahasiswa dalam belajar, maka perguruan tinggi sebagai lembaga pendidikan memiliki tanggung jawab untuk menghasilkan lulusan yang berkualitas dalam arti yang lebih luas dan mampu memenuhi permintaan dunia kerja, salah satunya adalah memiliki sikap mandiri sebagai suatu keterampilan (soft skill). 


\section{KESIMPULAN DAN SARAN}

Berdasarkan analisis data dan pembahasan hasil penelitian, diperoleh suatu kesimpulan bahwa sikap mandiri mahasiswa dalam perkuliahan matematika diskrit secara keseluruhan masih belum cukup baik, mahasiswa dalam belajar masih perlu dilakukan arahan dan pengawasan. Mahasiswa baru belajar ketika akan ujian dan ketika ada diberikan tugas tambahan. Apabila dilihat dari persentase tingkat kemandirian belajar mahasiswa secara keseluruhan lebih banyak pada kategori sedang, yaitu terdapat $57,54 \%$. Hal ini juga terlihat dari masing-masing aspek yang diukur untuk kemandirian belajar sebagian besar dari 4 (empat) aspek yang diukur berada pada kategori sedang yaitu lebih dari 50\%. Sementara itu masih dibawah $50 \%$ untuk kategori tinggi, dan tidak ada mahasiswa untuk kategori sangat tinggi, hanya pada aspek keyakinan dalam belajar terdapat $6,06 \%$ yang berada pada kategori sangat tinggi.

\section{DAFTAR PUSTAKA}

Akhdiyat, A. M., \& Hidayat, W. (2018). Pengaruh Kemandirian Belajar Matematik Siswa terhadap Kemampuan Berpikir Kreatif Matematis Siswa SMA. Jurnal Pembelajaran Matematika Inovatif Volume 1 Nomor 6, 1045-1054.

Bramucci, A. (2013). Self Regulated Learning; Theories and potensial apllications in didactics. University of Macerata, Lifelong Learning. Retrieved from http://intelligent-tutor.eu/files/2012/06/I-TUTOR_supportmaterial_selfregulated_learning_EN.pdf

Dina, \& Nugraheni, A. (2017). Profil Kemandirian dan Minat Belajar Mahasiswa Pendidikan Kimia pada Mata Kuliah Wawasan dan Kajian MIPA Melalui Pembelajaran E-Learning. Jurnal Inovasi Pendidikan Kimia Volume 11 Nomor 2, 1921-1931.

Glynn, S., Aultman, L., \& Owens, A. (2005). Motivation on learn in general education program. The journals of general of education volume 54 nomor 2, 150-170.

Haris, K., \& Graham, S. (1999). Programmatic intervention research; Illustrations from the evolution of self regulated strategy development. Learning Disablity Quarterly, 251-262.

Hendrayana, A. C., Thaib, D., \& Rosnenty, R. (2014). Motivasi Belajar, Kemandirian Belajar dan Prestasi Belajar Mahasiswa Beasiswa Bidikmisi di UPBJJ UT Bandung. Jurnal Pendidikan Terbuka dan Jarak Jauh, Volume 15 Nomor 2, 81-87.

Kemendiknas. (2010). Panduan Pendidikan Karakter di Sekolah Menengah Pertama. Jakarta: Direktorat Pembinaan SMP.

Monk, F., Knoers, A., \& Haditono, S. (2004). Psikologi Perkembangan: Pengantar Dalam Berbagai Bagiannya. Yogyakarta: Gadjah Mada University Press.

Mujiman, H. (2007). Manajemen Pelatihan Berbasis Belajar Mandiri. Yogyakarta: Pustaka Belajar.

Steffens, K. (2006). Self-regulated learning in technology enhanced learning environments: lessons of a european peer. European Journal of Education, 353-379. 
Syibli, M. (2018). Profil Kemandirian Belajar Siswa SMP dalam Pembelajaran Matematika. Jurnal Gantang Volume III Nomor 1, 47-54.

Tahar, \& Enceng. (2006). Hubungan Kemandirian Belajar dan Hasil Belajar pada Pendidikan Jarak Jauh. Jurnal Pendidikan Terbuka dan Jarak Jauh Volume 7 Nomor 2.

Trisianawati, E., \& Anita. (2016). Implementasi E Learning pada Mata Kuliah Fisika Llngkungan untuk Meningkatkan Kemampuan Berpikir Kritis dan Kemandirian Belajar Mahasiswa. Seminar Nasional Fisika (E-Journal) SNF Volume V. Jakarta: Prodi Pendidikan Fisika dan Fisika FMIPA, Universitas Negeri Jakarta.

Zimmerman, B., Bonner, S., \& Kovach, R. (2002). Developing self regulated learners: Beyond achievement to self efficacy. Washington, DC: American Psychological Assosiation.

Zumbrunn, S. (2011). Encouraging Self Regulated Learning in the Classroom . Virnigia Commomwealth University Metropolitan Educational Research Consortium. 